\section{The patient as person: an update}

\author{
Dawn P Richards
}

I live with a chronic, incurable disease called rheumatoid arthritis (RA). According to my healthcare system, this makes me a patient. But I can tell you I consider myself a lot of other things before I introduce myself to anyone as a patient or as a person who lives with RA. In fact those words (patient, person living with RA) are the ones I choose only when I'm in the healthcare system or when I'm part of some type of project that includes a patient perspective. Those words make me feel less empowered, less influential and less skilled than the others at the table in those situations. I am quite certain that when I'm in professional situations where I offer myself up as a patient, I am looked at 'differently' —and not in a 'good way' of differently.

\section{WHAT'S MY 'LABEL'?}

I contend that most patients don't identify themselves as a patient first and foremost-this is a label imposed on us by our healthcare systems. Sarah Riggare is a person who lives with Parkinson's disease and who uses a stunning visual and explanation to convey how little time she spends with her neurologist annually: 'I visit my neurologist twice a year, for about $30 \mathrm{~min}$. That is one hour per year. The rest of the year's 8765 hours, I spend in self-care'. ${ }^{1}$ This is similar to the time I spend annually with my rheumatologist-about 2 hours. I also spend a few hours for bloodwork and picking up my meds. That means I spend the other 8760 hours managing my RA on my own. I would take it one step further and argue that my rheumatologist is most definitely my medical expert, but he does not go home at night and live with RAthat is what I do, and so I'm the expert at dealing with RA daily.

I didn't think much about the label of patient until it was applied to me, thanks to my RA diagnosis, and I bet the same goes for people with an acute injury or illness. Living with an episodic chronic condition, or even an acute injury or illness, can feel out of control, unmanageable, and comes with fear for what the future may bring. Being recognised as a person who can work with a healthcare provider or providers to get to a personally meaningful place in life is empowering. It lessens the fear, provides some sense of control and alleviates some

Correspondence to Dr Dawn P Richards, Five02 Labs Inc, Toronto, ON M6R 2J6, Canada;

dawn.p.richards@gmail.com anxiety. As medical experts, you (BJSM readers) have likely considered how scared your patients are and how out of control their situations may feel to them. However, have you wondered if they really see themselves as a 'patient,' or if they see themselves as a person or an athlete first? Have you considered their self-label and in doing so, how that might change the dynamic between you and them, and maybe even the outcome of their treatment?

\section{PLEASE SEE ME FIRST AS A PERSON}

I wonder how my experience would be different if I was part of a healthcare system that saw me first as a person, and second as someone who successfully manages a chronic condition, checking in a couple of times a year for help. Currently, when I'm in my healthcare system, sure, I'm called by my name in the waiting room, but there are few pleasantries and most interactions must involve my provincial health card (in Canada this is how I 'pay' for my healthcare services) and sometimes a specific patient identification card for the centre where I'm seen. I'm pretty nameless from when I walk through the doors. Imagine if I was credited as a person successfully managing my RA for those 8760 hours of the year that I'm not sitting in a tiny, windowless exam room. Don't get me wrong, those 2 hours of care I receive from my rheumatologist are incredibly valuable to me, and they help reaffirm that I'm ok on my own with my RA. The patients you see have their own expertise in living with and dealing with their injuries and situations-no different from me and my RA.

We talk about our systems and approaches being all about the patient ('patient-centred' is popular as you know), but when patients aren't recognised as being people with their own goals outside of their conditions, I don't really think it's 'all about the patient.' In reality, things are mostly centred around the system-about the cards with my identification numbers, the forms and the timeslots for appointments. It takes time to change a system but I'd argue it doesn't take much to recognise someone as a person, or as an athlete or whatever descriptor is most important to that person at that time.

\section{A FEW RESPECTFUL SUGGESTIONS}

My respectful suggestions to care providers to consider are:

1. Ask for context related to a person's personal life and their ability to work with you. What things are most important to them in their life and what is their goal with respect to their injury and its healing? You may be surprised with what you find out.

2. Recognise the work someone has done and the effort they have taken outside of your office consultation to take your advice and manage to the best of their abilities. Respect how they have managed this given everything else they may have going on in their life at that moment.

3. Acknowledge that they may feel powerless and that much seems beyond their control. However, remind them of what is within their control and the power they have to make a difference.

4. Read the Patient Voices articles in BJSM and imagine yourself in the author's shoes. How would you wish to be treated? How would you feel? What would be important to you?

Imagine how being asked a few questions beyond the sports injury, or being provided with reassurance that they're doing a good job when they're not in your exam room or clinic empowers a person in a system and situation that otherwise feels threatening, out of control, and sometimes hopeless. Imagine giving people just that little nudge in their recovery or in their disease experience, to get back to being who they want to be, and allowing them to do what's important to them.

\section{Twitter Dawn P Richards @TO_dpr}

Funding The authors have not declared a specific grant for this research from any funding agency in the public, commercial or not-for-profit sectors.

Competing interests DR is founder of Five02 Labs Inc, a boutique consulting firm that provides scientific and patient based services to clients. Five02 Labs' revenues have included those from pharmaceutical companies (speaking fees, honoraria). Dr Richards is the vice president of the Canadian Arthritis Patient Alliance, a patient run, volunteer-based organisation whose activities are largely supported by independent grants from pharmaceutical companies. Dr Richards provides consulting services to the CIHR Institute of Musculoskeletal Health and Arthritis (Canada).

Patient consent for publication Not required.

Provenance and peer review Not commissioned; internally peer reviewed.

(c) Author(s) (or their employer(s)) 2020. No commercial re-use. See rights and permissions. Published by BMJ.

$$
\text { Check for updates }
$$

To cite Richards DP. Br J Sports Med 2020;54:1376.

Accepted 28 April 2020

Published Online First 10 June 2020

Br J Sports Med 2020;54:1376.

doi:10.1136/bjsports-2020-102418

\section{ORCID iD}

Dawn P Richards http://orcid.org/0000-0003-11510826 


\section{Editorial}

REFERENCE

1 Support The Guardian. Having Parkinson's since I was
13 has made me an expert in self-care. Available: https://www.theguardian.com/healthcare-network/ 2015/feb/19/being-diagnosed-with-parkinsons-at-13has-made-me-an-expert-in-selfcare 